\title{
Deteksi Dini Karsinoma Sel Basal
}

\author{
SUKMAWATI TANSIL TAN, MAHMUD GHAZNAWIE², GABRIELA REGINATA ${ }^{1}$ \\ 1Departemen IImu Kesehatan Kulit dan Kelamin Fakultas Kedokteran Universitas Tarumanagara, Jakarta \\ 2Departemen Patologi Anatomi Fakultas Kedokteran Universitas Hasanuddin, Makassar
}

Diterima: 14 Desember 2015, Direview: 15 Desember 2015, Disetujui: 5 Januari 2016

\section{KORESPONDENSI:}

Dr. dr. Sukmawati Tansil Tan, SpKK

Jalan Raya Serpong, Ruko Union Square No.9-11

Gading Serpong,

Tangerang 15810

Email:

sukma_ts|@yahoo.com

atau gabrela.reginata@

gmail.com

\begin{abstract}
Basal Cell Carcinoma (BCC) is a malignant neoplasm derived from nonkeratinizing cells that originate in the basal layer of the epidermis, which is locally invasive, aggressive, destructive, and rarely metastasize. BCC is more common in the elderly. Etiopathogenesis associated with BCC is genetic, environmental, and most often is exposure to ultraviolet light. Clinically, there are five types of BCC, which are nodular, superficial, morpheaform, pigmented, and fibroepitelioma Pinkus. Early detection of skin cancer can be done with self skin examination. Definitive diagnosis of malignancy is determined by anatomical pathology examination. However, for very early BCC lesion, it's difficult to determine with hematoxylin eosin staining. Therefore, it is uses Ber-EP4 staining which is specific and highly sensitive for early BCC growing as budding in basal layer of the epidermis and follicles. This finding is particularly significant in the development of molecular pathology and clinical management of BCC lesions or suspected BCC.
\end{abstract}

Keywords: basal cell carcinoma, malignant skin tumors, Ber-EP4

\section{ABSTRAK}

Karsinoma Sel Basal (KSB) merupakan neoplasma ganas dari sel yang tidak mengalami keratinisasi pada lapisan basal epidermis, bersifat invasif lokal, agresif, destruktif, dan jarang bermetastasis. KSB lebih sering terjadi pada usia lanjut. Etiopatogenesis yang berkaitan dengan KSB adalah genetik, lingkungan, dan yang paling sering adalah paparan sinar ultraviolet. Secara klinis, terdapat lima tipe KSB, yaitu nodular, superfisial, morpheaform, pigmented, dan fibroepitelioma Pinkus. Deteksi dini kanker kulit dapat dilakukan dengan pemeriksaan kulit sendiri (SAKURI). Diagnosis pasti keganasan ditentukan dengan pemeriksaan patologi anatomi. Namun, untuk lesi sangat dini KSB sulit ditentukan dengan pewarnaan hematoksilin eosin. Oleh karena itu, digunakanlah pewarnaan Ber-EP4 yang bersifat spesifik dan sangat sensitif untuk KSB dini yang tumbuh sebagai tunas di lapisan basal epidermis dan folikel. Temuan ini sangat berarti dalam pengembangan patologi molekuler dan penanganan klinis lesi KSB atau yang dicurigai KSB.

Kata Kunci : karsinoma sel basal, tumor ganas kulit, Ber-EP4

\section{PENDAHULUAN}

Kulit merupakan organ tubuh terluar yang melindungi tubuh manusia dari Lingkungan sekitar. Sebagai organ yang esensial dan vital, kulit mencerminkan kesehatan manusia, sangat kompleks, elastis, dan sensitif. ${ }^{1}$ Kulit tersusun dari jutaan sel. Normalnya, sel-sel di dalam tubuh akan membelah lebih cepat pada masa pertumbuhan, sedangkan pada masa dewasa sel akan lebih banyak membelah untuk menggantikan sel-sel yang mati atau untuk memperbaiki kerusakan jaringan. Sel 
kanker terjadi akibat kerusakan DNA. Sel kanker akan terus tumbuh dan membelah menjadi sel yang abnormal, juga dapat meluas ke jaringan yang normal. ${ }^{2}$ Pengawasan dan penemuan kanker kulit dapat dilakukan lebih teliti dan dini bila masyarakat memiliki pengetahuan yang baik, sadar, dan peduli akan kesehatan kulitnya, serta mau berkonsultasi ke dokter atau pusat kesehatan terdekat. ${ }^{3}$

Secara umum, kanker kulit dibagi menjadi melanoma dan non-melanoma. Yang termasuk kanker kulit non-melanoma adalah karsinoma sel basal dan karsinoma sel skuamosa. Karsinoma Sel Basal (KSB) merupakan keganasan kulit yang berasal dari sel non-keratinisasi basal sel epidermis. ${ }^{4}$ KSB disebut juga basalioma, epitelioma sel basal, ulkus Rodent, ulkus Jacob, atau tumor Komprecher., 3

\section{EPIDEMIOLOGI}

KSB merupakan penyakit kanker kulit yang terbanyak dijumpai, $75-80 \%$ dari kanker nonmelanoma. ${ }^{6}$ Menurut data Badan Registrasi Kanker Ikatan Ahli Patologi Indonesia (1989), dari 1530 kasus kanker kulit, yang terbanyak adalah kasus KSB (39,93\%). ${ }^{7}$ Di Amerika Serikat, insiden KSB semakin meningkat, dari 65\% pada tahun 1980 menjadi 80\% dari karsinoma kulit nonmelanoma pada tahun 2010. ${ }^{6}$ Perbandingan laki-laki dan perempuan adalah $3: 2 .{ }^{8}$ KSB sering terjadi pada usia lanjut, antara $50-80$ tahun, rata-rata sekitar 65 tahun. ${ }^{9}$ KSB yang diderita pada usia kurang dari 35 tahun berkisar 1-3\%, terutama pada pasien dengan sindrom nevoid KSB yang berpotensi menderita KSB pada usia muda. ${ }^{10,11}$

\section{ETIOPATOGENESIS}

Hingga saat ini, mekanisme pertumbuhan dan perkembangan KSB masih menjadi perdebatan panjang. Secara teori, etipatogenesis KSB berhubungan dengan faktor genetik dan lingkungan, terutama paparan sinar matahari UVB yang bergelombang 290 - 320 nm. ${ }^{4,12,13}$ Faktor genetik yang berperan pada KSB terdapat pada kromosom 1 dan satu varian dari setiap kromosom 5, 7, 9, dan 12, berhubungan dengan ketidakmampuan memproteksi terhadap paparan sinar matahari. Mungkin juga berkaitan dengan faktor risiko tambahan terhadap paparan sinar matahari yang bersifat heterozigot. Pada kelainan genetik yang bersifat homozigot seperti pada sindrom nevoid KSB atau sindrom Gorlin, berhubungan dengan Sonic Hedgehog Pathway signaling $(\mathrm{SHH}){ }^{8,14}$ Terjadi aktivasi kembali $\mathrm{SHH}$ yang seharusnya hanya aktif pada fetus. ${ }^{15}$

Faktor lingkungan yang dapat memicu terjadinya KSB adalah hidrokarbon, arsenik, coal, tar, obat topikal methoxipsoralen, dan sinar UV. ${ }^{12,16}$ Selain itu, rangsangan onkogen, kondisi imunosupresif, luka kronis, dan trauma akut juga terbukti menjadi faktor pencetus pertumbuhan lesi KSB. ${ }^{17}$ Pada kerusakan DNA terdapat pembentukan 6,4-photoproducts dan cyclobutane pyrimidine dimmers yang diperbaiki dengan Nucleotide Excision Repair (NER). ${ }^{18}$ Jika DNA repair gagal dan sel bersangkutan tetap hidup maka akan terjadi kerusakan DNA menetap. Ini berarti, telah terjadi mutasi dari gen bersangkutan. Radiasi UV-B meningkatkan apoptosis keratinosit untuk membunuh sel dengan kerusakan DNA gagal diperbaiki, terutama pada daerah yang aktif mengalami proliferasi pada lapisan basal epidermis. ${ }^{19}$ Jika mutasi ini mengenai gen yang menyandi sintesis faktor pertumbuhan (protoonkogen) atau yang menyandi sintesis faktor penghambat pertumbuhan (tumor supressor gene) maka karsinogenesis sudah berlangsung. Akumulasi mutasi gen inilah yang berperan dalam memicu terjadinya KSB. ${ }^{20}$

\section{DETEKSI LESI KSB DINI SECARA KLINIS}

Secara klinis, terdapat lima tipe KSB, yaitu subtipe nodulo-ulseratif, termasuk ulkus Rodent, subtipe berpigmen, subtipe morfea atau fibrosing atau sklerosing, subtipe superfisial, dan tipe fibroepitelioma., ${ }^{3,4}$ Subtipe nodular adalah bentuk yang paling sering dijumpai. Pada lesi dini sangat sulit ditentukan, dapat berwarna seperti kulit normal. ${ }^{3}$ Gambaran klinis awal berupa papul atau nodul kecil, translusen, berkilap seperti mutiara, telangiektasia, rolled border, pada perabaan keras seperti ada mutiara dalam kulit. $^{2-4}$ Lesi yang besar disertai nekrosis bagian tengah merupakan dasar terjadinya ulkus Rodent. ${ }^{3}$ Subtipe superfisial biasanya terdapat pada badan, berupa plak eritematosa dan tampak multisentris. Biasanya dihubungkan dengan ingesti arsenik kronis. Bentuk ini menyerupai penyakit Bowen, lupus eritematosus, psoriasis, atau dermatomikosis. ${ }^{2}$ Subtipe KSB berpigmen berupa papul translusen, hiperpigmentasi, dan dapat mengalami erosi. Subtipe morfea tampak sebagai plak sklerotik yang cekung, tumbuh secara agresif, berwarna putih atau kuning, berkilat menyerupai skar atau lesi morfea.,21 Fibroepitelioma Pinkus biasanya terdapat pada punggung bawah berupa papul merah muda tidak bertangkai atau bertangkai pendek, permukaannya 
halus, warna bervariasi, sulit dibedakan dengan akrokordon atau skin tag. ${ }^{2,22}$

Predileksi terutama pada 1/3 tubuh bagian atas, $75-80 \%$ di daerah wajah, yang tersering adalah hidung, nasal tip, dan alae nasi. Sekitar 25\% KSB berada di daerah badan, $5 \%$ di daerah penis, vulva, dan perianal. ${ }^{8}$ KSB bersifat destruktif, merusak jaringan kulit, tulang rawan hingga tulang di sekitarnya. ${ }^{23}$ Ulserasi pada area mata dapat merusak bola mata sampai orbita. ${ }^{3}$ KSB jarang menimbulkan metastasis. Pernah dilaporkan KSB bermetastasis ke kelenjar getah bening, paru-paru dan tulang. ${ }^{8}$
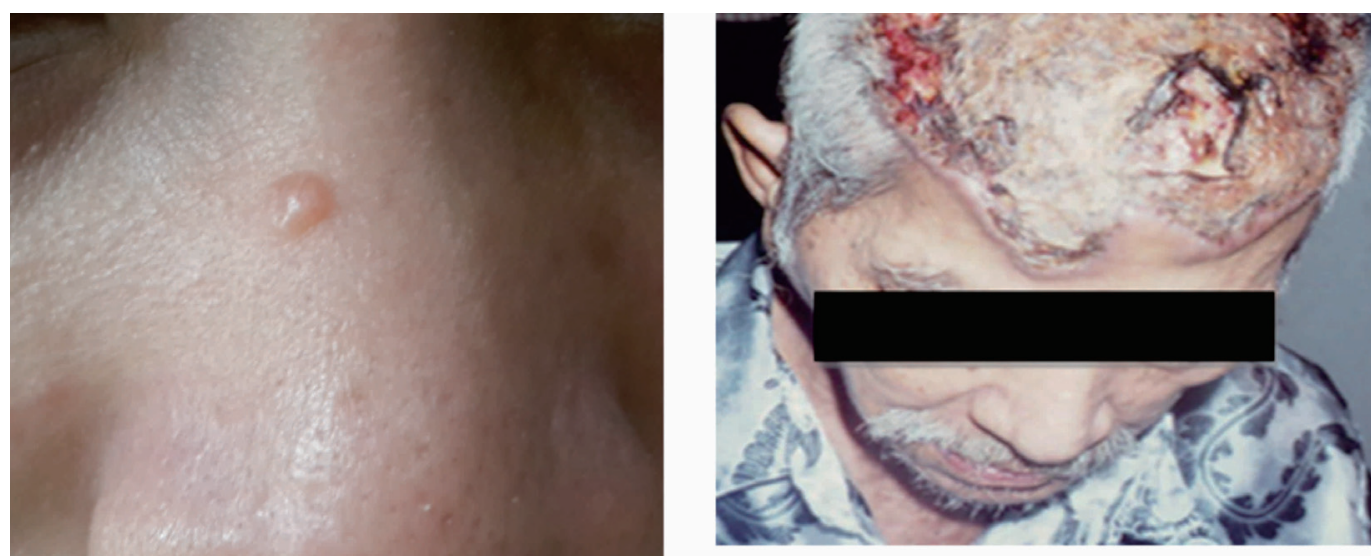

Gambar 1:

Nodul KSB pada hidung, $5 \times 5 \mathrm{~mm}$, mengkilap, telangiektasis dari tepi lesi menuju sentral, pada perabaan keras seperti mutiara (sumber: dokumentasi penulis)

Gambar 2:

Lesi sangat luas KSB di kulit kepala, $20 \times 20 \mathrm{~cm}$, berbatas tegas, tepi lesi meninggi, terdapat ulserasi dengan krusta tebal (sumber: dokumentasi penulis)

Diagnosis KSB ditegakkan berdasarkan anamnesis, pemeriksaan klinis, dan pemeriksaan histopatologi pada salah satu lesi untuk menentukan subtipe KSB. ${ }^{24}$ Sangat sulit membedakan bentuk dini KSB, karsinoma sel skuamosa, maupun melanoma maligna. ${ }^{2}$ Penderita KSB sering datang dengan keluhan bercak di wajah yang mudah berdarah dan tidak sembuh-sembuh, atau seperti tahi lalat (andeng-andeng) yang ukurannya bertambah besar, gatal, dan nyeri. Pentingnya deteksi dini KSB ditunjukkan seperti pada gambar 1 dan 2. Jika terdeteksi lebih awal (gambar 1), lesi belum meluas, tentu hasil pengobatan akan lebih baik. Pada lesi KSB yang dibiarkan dan akhirnya meluas (gambar 2), kecacatan yang timbul lebih besar, lebih sulit ditangani, secara kosmetik juga hasilnya kurang memuaskan. Karena diagnosis dini keganasan kulit sangatlah penting maka patut dicurigai beberapa gejala dan tanda keganasan kulit seperti yang akan diuraikan berikut ini.
Tabel 1: Anamnesis dan pemeriksaan obyektif curiga keganasan kulit²

\begin{tabular}{|l|l|}
\hline \multicolumn{1}{|c|}{ SECARA ANAMNESIS } & \multicolumn{1}{c|}{ SECARA OBYEKTIF } \\
\hline - Rasa gatal / nyeri & - Tidak berambut \\
- Perubahan warna (gelap, & - Warna suram (waxy, seperti mutiara, translusen) \\
pucat, terang) & atau sama dengan kulit normal \\
- Ukuran membesar & - Permukaan tidak rata, cekung di tengah, pinggir \\
- Pelebarannya tidak & agak menonjol (linear atau papular) \\
merata ke samping & - Penyebaran warna tidak homogen \\
- Permukaan tidak rata & - Skuamasi halus atau krusta yang melekat, bila \\
- Trauma & diangkat timbul perdarahan \\
- Perdarahan (walau & - Sering timbul tunas, bersifat seperti tumor induknya \\
trauma ringan) & - Perabaan berbeda-beda sesuai keadaannya; dapat \\
- Ulserasi / infeksi yang & keras, nyeri; tahap awal dapat digerakkan dari \\
sukar sembuh & dasarnya \\
& - Diameter terpanjang membentuksudut dengan \\
& garis rest skin tension line \\
& - Telangiektasia kadang ditemukan, mulai dari pinggir \\
& ke arah sentral \\
\hline
\end{tabular}

American Cancer Society menganjurkan agar memeriksakan kulit ke dokter setiap tiga tahun bagi usia 20-39 tahun dan setiap tahun bagi usia di atas 40 tahun. ${ }^{25}$ Selain itu, dapat juga dilakukan Periksa Kulit Sendiri (SAKURI), yaitu metode pemeriksaan kulit mandiri yang rutin dilakukan sebulan sekali 
dalam rangka mendeteksi dini kanker kulit. Dengan pencahayaan yang cukup, lakukan langkah-langkah SAKURI seperti gambar berikut.

\section{PEMERIKSAAN KULIT SENDIRI (SAKURI)}

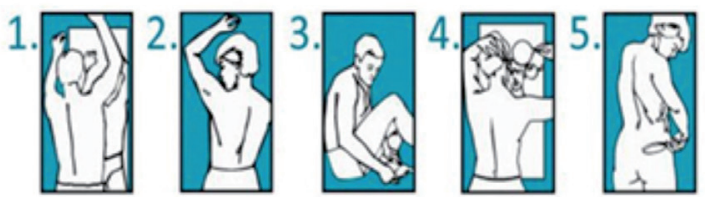

1) Periksa bagian depan dan belakang tubuh Anda dengan cermin, lalu ke bagian sisi kanan dan kiri dengan tangan terangkat.

2) Tekuk siku dan lihat dengan seksama di lengan, ketiak atas dan telapak tangan.

3) Lihatlah punggung kaki dan kaki, sela-sela jari-jari kaki dan telapak kaki.

4) Periksa punggung leher dan kulit kepala dengan cermin tangan. Bagian rambut untuk melihat lebih dekat.

5) Periksa kembali dan bokong dengan cermin tangan.

Gambar 3: Pemeriksaan kulit sendiri 26

\section{DIAGNOSIS LESI KSB DINI MELALUI PEMERIKSAAN PATOLOGI ANATOMI}

Diagnosis pasti keganasan ditentukan dengan pemeriksaan patologi anatomi (biopsi kulit). ${ }^{2}$ Pada umumnya, lesi dini KSB dapat dideteksi dengan pewarnaan Hematoksilin Eosin (HE). Pada pewarnaan $\mathrm{HE}$, lesi dini KSB tampak sebagai proliferasi sel basaloid di lapisan basal epidermis yang masuk ke dermis superfisial. Namun, ada beberapa lesi KSB sangat dini yang baru beberapa sel saja, terkadang sulit dideteksi dengan pewarnaan HE, bahkan tidak terdiagnosis karena ciri-ciri kelainan patologis belum prominen. ${ }^{27}$

Terdapat sebuah pewarnaan yang mampu mendeteksi lesi KSB sangat dini, yaitu dengan pewarnaan imunohistokimia (IHK) Ber-EP4. Antibodi Ber-EP4, suatu anti-human epithelial antigen, adalah suatu antibodi monoklonal yang berikatan langsung dengan glikopolipetida pada membran spesifik selsel epitel manusia dengan berat molekul 34-39 kilodalton, memberi hasil dengan reaksi positif kuat pada sel-sel epitel sehingga dapat digunakan untuk membedakannya dengan sel-sel mesotelial dan juga untuk diagnosis banding dengan undiffetentiated primary of metastatic tumor. ${ }^{28}$ Keunggulan IHK BerEP4 adalah mampu mendeteksi lesi KSB yang sangat sedikit (2-15 sel) sehingga sangat meyakinkan akurasinya untuk diagnosis dini KSB. Dengan IHK Ber-EP4, semua sel KSB terwarnai dengan intensitas yang sama, sedangkan sel basal normal tidak terwarnai. IHK Ber-EP4 bersifat spesifik dan sangat sensitif untuk KSB dini yang tumbuh sebagai tunas di lapisan basal epidermis dan folikel. ${ }^{27}$
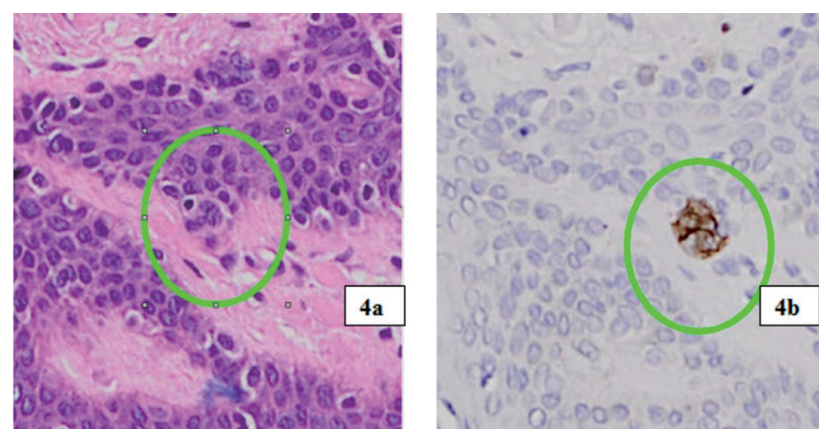

Gambar 4: Perbandingan pewarnaan HE dan IHK Ber-EP4 pada lesi KSB. 4a) Dengan pewarnaan HE, lesi dini KSB tidak jelas terwarnai. 4b) Dengan pewarnaan Ber-EP4, lesi dini KSB terlihat jelas ${ }^{27}$

Selama ini, klinisi memberikan perhatian utama pada kehadiran lesi KSB pada batas sayatan saat ekstirpasi KSB. Namun, penelitian Tan (2012) membuktikan bahwa lesi KSB sangat multipel. ${ }^{27}$ Jika klinisi menemukan lesi KSB yang sudah kasat mata, berarti kemungkinan besar ada pula sejumlah lesi KSB dini yang masih belum jelas terlihat dan lebih penting lagi untuk menentukan batas operasi suatu lesi apakah sudah bebas dari sel-sel KSB. Dengan kata lain, seseorang yang telah didiagnosis KSB dan telah diangkat tumornya harus diperhitungkan sebagai kelompok yang memiliki risiko tinggi munculnya lagi lesi KSB yang terdeteksi secara klinis, karena sebenarnya mereka sudah memiliki sejumlah KSB dini yang belum terdeteksi secara klinis. Hal ini penting karena menyangkut rekurensi KSB pasca-operasi, menentukan tindak lanjut, dan evaluasi post-operasi, khususnya tipe morfea (infiltratif) yang paling sering terjadi kekambuhan atau kelanjutan $\mathrm{KSB}^{29}$

Temuan ini sangat berarti dalam pengembangan patologi molekuler dan penanganan klinis lesi KSB atau yang dicurigai KSB. Ke depannya, IHK Ber-EP4 dapat pula dikembangkan untuk kepentingan pengobatan yang sekarang popular dengan molecularly targeted therapy pada penyakit kanker.

\section{DIAGNOSIS BANDING}

KSB tipe nodular didiagnosis banding dengan nevus dermal, karsinoma sel skuamosa, tumor adneksa kulit, dermatofibroma, sikatrik, dan keratosis seboroik. Untuk KSB berpigmen, diagnosis bandingnya adalah melanoma nodular, melanoma dengan 
penyebaran superfisial, lentigo maligna, blue nevus, compound nevus, dan tumor adneksa kulit. Diagnosis banding KSB superfisial adalah penyakit Bowen, penyakit Paget, melanoma dengan penyebaran superfisial, psoriasis, dan eksema. Tipe morfeaform, lesinya menyerupai morphea, sikatrik, dan trikoepitelioma. Fibroepitelioma Pinkus didiagnosis banding dengan skin tag, fibroma, dan papillomatous dermal nevus. ${ }^{3,4}$

\section{KESIMPULAN}

KSB merupakan tumor kulit ganas yang berasal dari sel nonkeratinisasi lapisan basal epidermis. Faktor genetik dan lingkungan, terutama paparan sinar matahari, berhubungan dengan etiopatogenesis KSB. Diagnosis dapat ditegakkan melalui anamnesis, pemeriksaan klinis, dan histopatologi. Gejala dan tanda keganasan kulit penting untuk diketahui. Melalui pemeriksaan kulit sendiri (SAKURI), kanker kulit dapat dideteksi lebih awal. Pemeriksaan patologi anatomi dilakukan untuk menegakkan diagnosis pasti KSB. Namun, pada lesi sangat dini dengan jumlah sel kanker yang masih sedikit, KSB kadang tidak teridentifikasi. Dengan pewarnaan IHK Ber-EP, lesi KSB dini dapat dideteksi dengan akurat. Keunggulan Ber-EP4 berguna dalam penanganan klinik lesi KSB, pengembangan ilmu patologi molekuler, dan mampu menjadi solusi untuk kasuskasus variant KSB yang sulit dibedakan dengan penyakit lain.

\section{DAFTAR PUSTAKA}

1. Wasitaatmadja SM. Anatomi kulit. Dalam: Djuanda A, Hamzah M, Aisah S, penyunting. Buku Ilmu Penyakit Kulit dan Kelamin. Edisi ke-VI. Jakarta: Badan Penerbit Fakultas Kedokteran Universitas Indonesia. Anonymous. Melanoma Skin Cancer. American Cancer Society 2005;201:1-52.

2. Rata IGA. Tumor kulit. Dalam: Djuanda A, Hamzah M, Aisah S, penyunting. Buku Ilmu Penyakit Kulit dan Kelamin. Edisi ke-6. Jakarta: Badan Penerbit Fakultas Kedokteran Universitas Indonesia, 2005;229-41

3. Carucci JA, Leffel DJ. Basal cell carcinoma. Dalam: Wolff K, Goldsmith LA, Katz SI, Glicherst BA, Paller AS, Leffel LJ, penyunting. Fitzpatrick's Dermatology in General Medicine. $7^{\text {th }}$ ed. New York: Mc Graw-Hill; 2008.h. 1036-42.

4. Rubin AI, Chen EH, Ratner D. Basal cell carcinoma. N Engl J. Med. 2005; 353: 2262-9.
5. Panda, S. Non-melanoma skin cancer in India: current scenario. Indian J Dermatol. 2010; 55(4): 373-8.

6. Tjarta A. Spektrum kanker kulit di Indonesia. MDVI 1995; 3(22): 100-6.

7. Bader RS, Santacroce L, Diomede L, Kennedy AS. Basal cell carcinoma. October 2014 [cited 2015, 22 ${ }^{\text {nd }}$ Feb] Available from URL:

8. http://emedicine.medscape.com/article/276624-overview

9. Tiftikcioglu YO, Karaaslan O, Aksoy HM, Aksoy B, Kocer U. Basal cell carcinoma in Turkey. J Dermatol. 2006; 33(2): 91-5.

10. Bergman A, Contard P, Spencer J. Multiple basal cell carcinoma in a young adult treated with Imiquimod 5\%: a case report and literature review. January 2005. [cited 2015, 22 ${ }^{\text {nd }}$ Feb] Available from URL:

11. http://jddonline.com/articles/dermatology/S1545961605P0095X/1

12. Barankin B. Goldenberg G. Nevoid basal cell carcinoma syndrome. January 2015. [cited 2015, 22 ${ }^{\text {nd }}$ Feb] Available from URL: http://www.uptodate.com/contents/nevoid-basal-cellcarcinoma-syndrome

13. Tilli CM, Steensel MA, Krekels GA, Neumann HA, Ramaekers FC. Molecular aetiology and pathogenesis of basal cell carcinoma. Br J Dermatol. 2005; 152: 1108-24.

14. Cohen PR, Schulze KE, Nelson BR. Basal cell carcinoma with mixed histology: a possible pathogenesis for recurrent skin cancer. Dermatol Surg. 2006 Apr; 32(4): 542-51.

15. Muzio L. Nevoid basal cell carcinoma syndrome (Gorlin syndrome). Orphanet J Rare Dis. 2008 Nov; 3: 32.

16. Donovan J. Review of the hair follicle origin hypothesis for basal cell carcinoma. Dermatol Surg. 2009;35(9):1311-23.

17. Cohen P, Schulze K, Nelson B. Basal cell carcinoma with mixed histology : a possible pathogenesis for recurrent skin cancer. Dermatol Surg. 2006;32(4):542-51.

18. Kasper $\mathrm{M}$, et.al. Wounding enhances epidermal tumorigenesis by recruiting hair follicle keratinocytes. Proc Natl Acad Sci U S A. 2011 Mar; 108(10): 4099-104.

19. Rass K, Reichrath J. UV damage and DNA repair in malignant melanoma and non-melanoma skin cancer. 2008; 624: 162-78.

20. Dallaglio KA, Marconi A, Pincelli C. Survivin: a dual player in healthy and diseased skin. I Invest Dermatol. 2012; 132: 18-27.

21. Mimeault M, Batra SK. Recent advances on skin-resident stem/progenitor cell functions in skin regeneration, aging and cancers and novel anti-aging and cancer therapies. 2010. J Cell Mol Med. 2010; 14(1-2): 116-34.

22. Wong CSM, Strange RC, Lear JT. Basal cell carcinoma. BMJ. 2003; 327: 794-8.

23. Telfer NR, Colver GB, Morton CA. Guidelines for the management of basal cell carcinoma. Br J Dermatol. 2008; 159: 35-48

24. Puri T, Gunabushanam G, Sharma R, Kumar S, Julka PK. Extensive bone metastases from basal cell carcinoma of the eye. Singapore Med. 2006; 47( 9): 811-3. 
25. Handayani I, Kuswadji. Penatalaksanaan karsinoma sel basal MDVI 1999; 1(26):28-34

26. American Cancer Society. Atlanta: American Cancer Society, 2015.

27. Sekretariat Komite Penanggulangan Kanker Nasional (KPKN). Jakarta: KPKN, 2015
28. Tan ST. Identifikasi lokasi dan stem cell origin serta faktor yang mempengaruhi lemahnya kemampuan metastasis karsinoma sel basal. Makassar: Fakultas Kedokteran Universitas Hasanuddin; 2012.

29. Lajhta LG. Stem cell concepts. Differentiation 1979; 14(12):23-34. 